\title{
MULTICULTURALISM AS THE RELIGION OF POLITICS
}

\section{Constantin NECULA*}

\begin{abstract}
Marked by both social and cultural fragmentations, Western Europe seeks a restructuring of culture, in order to provide a balance of both its social and spiritual context. A radical democracy that sanctifies diversity (1980-1990) opposes the Conservatism of resistance (19681980 ) and is exhausted today in an effort to normalize values, which is marked in its turn by an unexpected element, which is called by classical sociology researchers "liberal radicalism" that is born of the conflict between the sociology of diversity and inclusive sociology. The church is caught between her ideal, as the people of God, and the European ideal, a new people with no national identity. The ideology of globalization becomes the strength of manufacturing this European people. Conservatism is opposed to Cultural Marxism. Is it a solution, especially when using Christian ethical elements, in order to instill political contents? Thus is born the tension of multiculturalism, facilitating a democracy of diversity at the expense of the democracy of representativeness.
\end{abstract}

Keywords: cultural fragmentation, multiculturalism, democracy of diversity, social pedagogy

Among the biggest political temptations of the modern world, the sacralization of diversity and the dilution of religion into the absurd of multiple syncretic forms have given birth to what experts call today multiculturalism. We face an inflation of communication technology that determines the explosion of a vocabulary of this syncretism, which builds a political religion, which is often called Cultural Marxism. The

PhD, Rev., Associate Professor, 'Andrei Şaguna' University (Faculty of Orthodox Theology), Sibiu, Romania. 
discourse of the political and cultural modern world has proposed forefront terms for the construction of this discourse. Human empowerment goes through the logic of egalitarianism, in the sense of extending it to everything that is socially connected, and by recognizing multiple identities that in every age are increasingly reduced to the total dilution of consensus. Diversity is valuable, but not everything that is at all costs touched by the ideology of diversity enriches human nature value or its living treasure.

Thus a new political legitimacy is born and proposed, on which Mathieu Bock-Cote ${ }^{1}$ insists that it is the political expression of what sociology calls a project, and political science understands as continuous socio-ethical and cultural adaptation. For the theologian the reading list becomes mandatory to understand their concepts and developments in the writing of some remarkable authors. Francisc Fukuyama, Raymond Aron, Georges Pompidou with his 1968 speeches, Maurice Druon, Alain Touraine or Philippe Raynaud are ideologists of a realistic analysis of what we should call "the cultural war". The image that remains is that of the fragmentation of values, of a culture that invades by immersion in the media and is reduced to polymorphisms that lack ethical rigor.

'Liquid World', Zygmund Bauman's favorite concept ${ }^{2}$, proposes a reconsideration of the moral bases of the incisive political religion that is multiculturalism.

Bock-Cote insists on identifying some turning points of this ideology: democracy against democracy, by instituting the natural history of equality ("retour" - Tocqueville), the history of the end of the war and the political end of the great ideas - birth of the cultural war, the changes of the Left - criticism of capitalism and Western civilization, radical democracy and sacralization of diversity (during 1980-1990),

1 Mathieu Bock-Cote, Le multi-culturalisme comme religion politique, Paris, Les Editions du Cerf, 2016.

2 See an excellent image of his thinking in the volume Conversazioni su Dio $e$ sull'uomo, in collaboration with Stanislaw OBIREK, Edizioni Laterza, 2016, 175 p. Some of the titles that we have consulted in Italian are worth mentioning: Iubirea lichidă. Asupra fragilității legăturilor afective; Demonul fricii; Etica într-o lume de consumatori; Europa este o aventură; Modernitatea lichidă; Modus vivendi. Infernul și utopia în lumea lichidă; Viața lichidă; Vieți ce nu ni le putem permite etc. 
Third Way phenomenon and normalization of radicalism management and of the strategies related to values, the political restructuring of democracy, era of apologies and repentant commemorations century pedagogy of repentance, clotting memory of multiculturalism. Thus we notice both the birth of sociology of diversity and the inclusive sociology that originated the victimizing identity and minorities' identity alike, which expresses itself through the self-discriminatory sociology as critical element of liberal democracy. Hence there are built two branches of multiculturalism as religion: the "manufacturing" of a new people, by means of the radicalized Contractualism, and by globalization ideology based on globalized civil society. The most serious conclusion of his work brings us to the sphere of political thinking: censoring Conservatorism of all kind and limiting the democratic consensualism bring us to the sphere of tribal politics in the sense identified in Romania by Vasile Dâncu ${ }^{3}$ or in Steve Silberman's excellent analysis of autism as a phenomenon ${ }^{4}$, and bring us closer to totalitarianism. Examples of countries of the democratic world, which are on the brink of integration into the EU family such as Turkey, force us to deepen the theoretical risks.

In this regard, an analysis proposed to the Romanian public is relevant. The author is Neil Postman (born in 1931) ${ }^{5}$, a well-known social critic and theorist of education in the US, originator of the famous study program in Media Ecology of New York University. First published in 1985 as an extended version of a discourse at the Frankfurt Book Fairbreed in 1984, the book belongs to the relevant books for the present-days. It stands in close spiritual relationship both with Aldous Huxley's Brave New World and with George Orwell's 1984, authors that marked Postman's way of thinking: "Orwell feared those who would ban books. Huxley feared that there would be no reason to ban them, because there would be no one who wants to read them. Orwell

\footnotetext{
${ }^{3}$ Vasile Sebastian DANCU, Triburile. O patologie a politiciiromânești de la Revoluție la Generația Facebook, ClujNapoca, EdituraȘcoalaArdeleană, 2015, 321 p.

${ }^{4}$ Steve Silberman, Neurotriburi. Istoriauitatăaautismului, București, Frontiera, 2016.

5 Neil Postman, Distracția care ne omoară. Discursul public în epoca televizorului (Amusing Ourselves to Death. Public Discourse in the Age of Show Business), București, Anacronic, 2016.
} 
feared those who would deprive us of information. Huxley feared those who would give us so much information that we will be thrown into passivity and egoism. Orwell feared that the truth would be drowned in an ocean of irrelevance. Orwell feared that we would become a captive culture. Huxley feared that we would become a trivial culture, preoccupied with tactile, debauchery, drunkenness and throwers of centrifugal balls. As Huxley noticed in Brave New World Revisited, libertarians and rationalists, who were in a permanent alert in order to face tyranny, have failed to take into account man's almost insatiable appetite for entertainment. In 1984, Huxley adds that people are simply controlled by inducing them pain. In Brave New World, people are controlled by inflicting them pleasure. In short, Orwell feared that we will be destroyed by what we hate. Huxley feared that we will be destroyed by what we love. This book is about the possibility that Huxley, not Orwell, was right" 6 . Environment as a metaphor, media as epistemology, printed and online thinking are points of tension from which every theologian that is preoccupied with the world discourse can start a potential analysis.

Marked by both social and cultural fragmentations Western Europe seeks for restructurings of the culture in order to provide a balance of social and spiritual context alike. A radical democracy that sanctifies diversity (1980-1990) opposes to Conservatism of resistance (1968-1980) and is exhausted today in an effort to normalize the values, which in its turn is marked by an unexpected element that is called by classical sociology researchers ,liberal radicalism” born of the conflict between the sociology of diversity and inclusive sociology. An example is gender egalitarianism diverted to the purest politics. The today extremely claimed sexual equality is by no means ethical celebration of diversity, but the abolition of complementarity between man and woman through policies. This ends in a cultural and anthropological inanity, a nirvana called gender balance, which develops a false power parity redistribution related to individualization and deconstructivist segregation reaching the theories of the Australian Peter Singer (1946), who proposed in Animal Liberation the conscious abolition of the

${ }^{6}$ N. Postman, op.cit., p. 13-14. 
ARS LITURGICA. From the Image of Glory to the Images of the Idols of Modernity distinction between man and animal ${ }^{7}$. Hence the image of the string of letters: LGBTQ +, a highly doubtful "+".

One of the most relevant readings of this phenomenon is proposed by Giancarlo Ricci, psychoanalyst and theorist of the gender phenomenon, who divulges the anthropological amputation caused to the culture of the modern world by terminology undertaken religiously by multiculturalist culture: gay unions, "monogenitum" adoption, hetero-fertilization. In the name of modernism needs are excluded from modern (or postmodern) human culture some symbolic or identity references that were established in the ontology of human culture. It follows a denial of the human psyche and starts the public celebration of the triumph of narcissism of the ego cut off from the common good ${ }^{8}$. Hence, the requirement to call cultural communism such multicultural proposals, because they retain in themselves the captivity of normality in ordinary prisons of public opprobrium. Inquisitorial fundamentalism promoted by politically correct attitude leads to depreciation and disapproval of democratic structure that supports it. The ideological politics courses promoted in the LGBTQ+ centers lobby of or other useless freedoms led to chain reactions of some Christian civil societies in France, Italy, Hungary and Turkey, the last two reacting on behalf of their religious fundamentalism. Situations like Brexit are presented somehow culpable as well as the amount of tensions related to the military intervention in the former Yugoslavia. We should not forget that Belgrade was bombed on Easter days on behalf of multiethnicity and multiculturalism. Affecting the generally accepted popular thinking under the pressure of some advocacy groups shows again that R. Aron's saying is correct. He warned that the big proletarian movements of the world are in fact the product of some groups of intellectuals decided to determine the population to act as if it were something spontaneous. Excerpts from theoretical postulation of the world to Lenin, Marx, Engels, Trotsky or liberal Gorbachev determine today the alarming number of concepts belonging to liberalized intellectualism and

7 Margherite A. PEeters, Il Gender. Una questione politica e culturale, San Paolo, 2014, p. 118-119.

8 See an ample presentation of the topic in Giancarlo RICCI, Sessualita e politica.

Viaggio nell'arcipelago gender, Sugarco Edizioni, 2016, 235 p. 
constitute the enlarged Decalogue of a universal religion: religion of new man, always in opposition to immemorial humanity.

The church is caught between her ideal, as people of God, and the European ideal, as a new people without national identity. The ideology of globalization becomes the strength of manufacturing this European people. Conservatism opposes Cultural Marxism. Is it a solution, especially when using Christian ethics elements, in order to instill political contents? Thus, the tension of multiculturalism and facilitation of a democracy of diversity arise at the expense of democracy of representativeness. The solution of active populism becomes outdated and easily diverted ${ }^{9}$.

Perhaps no such social and cultural dilution would be important in the Church's missionary ethos if it would not suggest the birth of a new temptation: totalitarianism. Hence the resistance to multiculturalism and developing canonically based mystical reservations in Orthodoxy; hence the nationalist reaction of both German and French people, clotting around some anti-multicultural leaders in Great Britain (Brexit belonging to the cultural themes, not to the economic area). Is European theological thinking able to help, to assess, diagnose and avoid a macrocultural tragedy? Signs could be identified including analysis of social pedagogy. An example might be Josh McDowell's approach to fulfill his difficult task of redefining the alien generation; an online generation but alienated and affected by depression caused by discontinuous connection. A generation facing hyperconnectivity and hypercommunication defined itself as living "in a virtual reality almost lacking in adults" (Hill Walker, codirector of the Institute on Violence and Destructive Behavior) ${ }^{10}$. But what is the hard core of such encouraged alienation? They come from years 1987 and 1994 to us according to the specialists, but in accordance with the theme of multicultural religious. Mc Dowell noticed: „The latest equipment (year 2000, n.NC), which allow our children to connect electronically with people around the world could, at the same time encourage them to break off the relations with the people living in their own home. In more

${ }^{9}$ See the analysis by Jose Luis Villacanas, Populismo, Huerta Grande Editorial, 2015.

10 Josh McDowell, Generația înstrăinată. Un pod peste prăpastia dintre generații, Oradea, Scriptum, 2005, p.18. 
ARS LITURGICA. From the Image of Glory to the Images of the Idols of Modernity and more dwelling-places, students have their own computers, modems and telephone lines. And since many homes are equipped with computers for Mom and Dad, children and their parents spend more time staring at screens than having a real interaction with one another. However wonderful may be the computers for some purposes, they can contribute imperceptibly to the alienation of a generation. Meanwhile children spend hours on Internet, talking to different people, playing online games, having less time to interact with the others, especially with their parents and other adults in the family. Also, adults who are concerned in a similar measure with Internet, career, social and religious activities risk themselves to alienate. Every serious sociological study of the last fifteen years that examines human relationships or their absence and human behavior shows the following: if a person has no strong ties of relationship, it is more likely that he/she will be involved in antisocial acts"11. The author himself was the initiator of two studies in the Church (and therefore a little bit more cautious concerning the ideological corruption, we shall say), that demonstrated this: the closer is the relationship a youngster has with his parents, the less is the risk of his embracing unacceptable behaviors.

Data proposed by him become alarming not because they express a correct image of figures, but because they cover the reality of many Romanian families and communities:

- $50 \%$ of contemporary young people have experienced the divorce of their parents or live in a climate of pressure concerning the topic;

- $63 \%$ of young people live in families where none of the parents work at home or at an advantageous distance to intervene in favor of the child;

- only $25 \%$ of children can say that their mothers are at home when they come back from the school;

- $98 \%$ of young people spend eleven hours watching the screens (TV, iPhone or iPod);

- teenagers spend about three and a half hours alone / day.

It is clear and time has confirmed that the adolescents belonging to the alien generation have become the dyslexic adults of the alien generation in terms of communion. Sympathy transmitted through multiculturalism does not produce a responsible cultural reality. The

11 J. McDowell, Generația înstrăinată..., p. 19-20. 
most readily available examples are those from the multiethnic and multicultural environment in Strasbourg. The testimony of a French teacher, who was also head teacher of a class in one of the Catholic colleges and has a decade-long experience both in teaching and immediate pastoral field as wife of an Orthodox priest, proved to me once again the danger of cultural mélange. When she explained to her students a series of literary themes, she came to the moment when she had to express the relationship of a character with Christian Fasting. Despite the fact that her students were in a Catholic college, they had no idea about such a thing. Finally they exclaimed: "Ah, it's like Muslim Ramadam!" Another time, when she organized a visit to Venice in terms of comparative literature, in the special week of the college, a desperate mother comes to the bus that was ready to leave and asked her: "Are there churches in Venice?" The teacher answered: "Of course, they are!" And she tells her something about what she had already included in the text of the travel support brochure. Then the mother reacted: "In that case, our daughter will not go with you anymore. We are agnostic". Of course, it could be an isolated and insignificant case and on the other hand there is a reaction of ultra-Orthodox parents against a series of school activities, but while Church encourages the integration of children in schools collective and their education based on the family values, multiculturalism as religion invites them to adopt educational clichés and to reject the family authority concerning sexual or moral matters, proposing the culture of counter-culture.

In 1849 Antonio Rosmini was printing his most famous book, which he had started in 1832: The five plagues of the Holy Church. Principles of Christian Fulfillment"12. Versed in the principles of liberalism that would shake Europe in 1848 and would give the European world the democratic culture of the appearances of the emancipated nations, Rosmini offered in his work a meditation on the issue on the Church-Society relationship. He noticed five plagues:

1. the plague in the left hand of the Holy Church: the separation between the people and the clergy during divine service;

12 Antonio Rosmini, Cele cinci plăgi ale Sfintei Biserici. Principii pentru desăvârșirea creștinească (Treaty dedicated to Catholic clergy), Rom. transl. by Raluca Popescu, Iași, Institutul European, 2007, 327 p. 
2. the plague in the right hand of the Holy Church: the insufficient education of the clergy;

3. the plague in the rib of the holy Church: the lack of union between bishops;

4. the plague in the right foot of the holy Church: the designation of the bishops was left to the laity power;

5. the plague in the left leg: servitude of ecclesiastical goods.

Beyond the idea that these plagues continue to affect the administrative body of the Church, they obviously have become the plagues of the new multicultural order of the world. A multiculturalism that divides people from the "intelligentsia" in the process of social life, which a group formed of insufficiently educated leaders despite many university degrees and certificates, or precisely because of the many training programs that damage their critical, innovative thinking. The lack of unity of leaders and of those who assume policies, or the designation of political leaders that is constantly directed according to the current interests of the political curricula, through media induction, is often a present plague. It is no longer necessary to insist on the last plague that can be clearly emphasized with thousands of news about corruption and the negative impact on the economic and many interests in the field. Rosmini's solution is simple: the personal effort of everybody who undertakes social and institutional responsibilities. Multiculturalism has replaced the need of the people to relate to the Gospel with reference to the shortcomings of conjectural laws and has created a code of laws that always need to appeal to internationalism. It is a kind of religion without borders, implying a series of reactions of mentality and discernment, without which it would be lost in the abyss of a permanent inadaptability.

Is Church that "obdurate fortress" in that it dominates the position of legitimacy based on nature and tradition, which was so vehemently disputed by Aristotle? Or did the Church constitute and does it still constitute the most desired solution of the absolute utopias of all democratic educations by opposing the natural, legitimate situation a set of norms and regulations that hinder the law of the mighty? Whether it 
is the oligarch or the poor and manipulable "demos" multiculturalism the entire legal background is shifted to a democracy of those who own funds for lobbying, another form of legal oligarchy. For them "sect" is the other ${ }^{14}$, a definition from which the Church escaped long time ago and rethinked it at the Synod in Crete (16 to 26 June 2016) ${ }^{15}$, as it is seen especially in the most incriminated document (by the Orthodox proletcultism), with the title "The Relation of the Orthodox Church with the rest of the Christian World".

The last aspect related to the dimension of multiculturalism as religion of the politic is emphasized in Pierre Manent's work Situation de la France, Desclée de Brouwer ${ }^{16}$. He identifies a series of actions of politics meant to refresh multiculturalism, with its abnormal political legitimacy as religion. His analysis is constructive, so we mention some aspects: "Islam will not be inserted into Europe simply advancing on the human rights field, emptied of any kind of common substance and passively open to any new content. It will not even enrich or disturb European culture, politically undetermined court that cannot provide the resources of action. It will or will not be accepted, it will be well or badly received by the various European nations, depending on how they will or will not find their capacities to react. In spite of what almost all parties believe, the only chance of a successful participation of Islam in European life depends on the strengthening rather than the disappearance of nations. Islam can only be accepted in an active community that employs it and drives it to participate in res publica, while in a mechanism without a common goal in which everyone's rights are guaranteed and respected, it will not be anything but a burden. Over time, the governors who alternate to power gave up to address

${ }^{13}$ Emil STAN, Spațiul public și educația la vechii greci, Iași, Institutul European, 2003, p. 27-28.

${ }^{14}$ Jean-Francois MAYER, Sectele. Neconformisme creștine și noi religii, rom. transl. by Ruxana Pitea, București, Enciclopedică, 1998², p. 5.

${ }^{15}$ Official Documents of the Holy and Great Council of the Orthodox Church (16- 26 June 2016, Crete) can be consulted in the Romanian language: http://basilica.ro/documentele-oficiale-ale-sfantului-si-marelui-sinod-in-limbaromana/. For English: https://www.holycouncil.org/.

16 Pierre Manent, Musulmanii, obstacolul inedit, translation and notes by Cristian Preda, Iași, Adenium, 2016, 158 p. 
Muslims in France as participants in a joint action, for they even gave up on the idea of a joint action in which «France» is an element, agent and object. For there is no question of their working together with Muslims, and how they are still part of the nation's life, there is nothing else left but to make them disappear, destroying everything that we have in common and actually form our own country. This prestigious operation is obviously extremely difficult, so it must always be repeated. However, governments that have long time ago given up the ambition of guiding our actions, are full of zeal when it comes to organizing our perceptions. In fact, they think it is right to decide what we should look at. Since perceptions do not have a social existence, but only the word, it is proper for words to be controlled with severity. How can you make the Muslims in France disappear by the magic of words? The first step is the refusal to name non-Muslims, because if you did that, you would give consistency to a large group, from which Muslims would be excluded. For this purpose, it should be avoided to name all the things that we have in common, but to which Muslims do not participate and from which they may declare themselves excluded, even though it depends only on them to join us. It applies firstly to Christian religion. It is known what efforts did the President of the Republic to avoid calling its name, implicitly when naming it would have been natural and even necessary. In any case, the ancient inhabitants of this country cannot be named by reference to any of their collective affiliations, but by designating them in this way, the rule is violated. And if you cannot name the non-Muslim, then the only participants in the social life likely to be named are Muslims: We wanted to make them disappear from the landscape, and they are the only ones who have a legitimate name! What shall we do? How can we make Muslims disappear after we have made the non-Muslims disappear? Well, forbidding them to be called! But don't we name them when we strive to guarantee their citizens' rights and verify if they are respected? The notion of «Islamophobia» has therefore been borrowed from Islamic propaganda and it plays today a major and very disturbing role in our social and political life. It has no sense, but it has a function. This notion allows the gradual indictment of any reference to Islam or Muslims. Who starts a sentence with the notion «Muslims» knows he must heed the words that follow as the offense does not delay to come. It is therefore not possible to speak 
calmly about Muslims than to express the legitimate complaints they are addressing or that they might address to the rest of the social body, which in this case can be named. We can, for example, talk about Muslims to say they have few mosques, but also about Christians that have too many churches" 17 . On a broader scale, the author identifies a highly precious mechanism of political religiosity. Muslims or homosexuals - I do not confuse minorities, even if it happened to the president of another Republic - express themselves in society only to complain legitimately and the legitimate discourse about them is accomplished by accompanying their legitimate complaint. Phobias built in this way, either as a language or a spearhead of social communication, prove a false social valorization. We set from the start either Muslim or LGBTQ + in the situation of a minority that laments, as a temptation that has revealed the weakness of European governments. They have placed Muslims and activists for minorities many of them mere officials of an ideology, in the condition of a general and eternal minority. In fact, we say sometimes through the law that they are not able to participate in normal social life built on the normal exchange of views and ideas. Social hostility on such concepts reveals that beyond any brainwashing there is the educational resistance.

Perhaps this is the continuous struggle between the forced secularization of Law State and Christianity. A complex, tense or sometimes polemical issue ${ }^{18}$, was brought in the Romanian dialogue market by people who amazingly confuse the Western laity with that one specific to Orthodoxy or to Romanian space, proving - how many times? - that sectarizing the Romanian culture by the lack of knowledge or the insolence of the reasons cannot replace culture, especially in dialog, just as thinking of secularization of Romanian space within the boundaries of Western secularization proves a weak knowledge of its anthropological dimension ${ }^{19}$ and of the Christian culture specific to

${ }^{17}$ P. MANENT, op.cit., p. 105-107.

18 Philippe CAPELle-Dumont, "Laicite et christianisme. Nouvelle questions", in Académiecatholique de France (ed.) Laïcitéetchristianisme, Paris, Parole et Silence, 2015, p.7-23.

19 Yves LEDURE, Sécularisation et spiritualité: approche anthropologique du christianisme, Bruxelles, Lessius, 2015. 
Orthodoxy. That is why we believe that a topic opened by our brief research may be a critical analysis of the way in which the labels of humanist and liberal slogans can affect the religious culture of the person and the Romanian, European and Christian citizen's freedom of thinking.

\section{References:}

1. Bock-COTE, Mathieu, Le multi-culturalismecomme religion politique, Paris, Les Editions du Cerf, 2016.

2. CAPElle-Dumont, Philippe, "Laicite et christianisme. Nouvelle questions", in vol. Academie Catholique De France (ed.), Laicite et christianisme, Paris, Ed. Parole et Silence, 2015, p.7-23.

3. BAUMAN, Zygmund/ OBIREK, Stanislaw, Conversazioni su Dio e sull'uomo, Edizioni Laterza, 2016.

4. DÂNCU, Vasile Sebastian, Triburile. O patologie a politicii românești de la Revoluție la Generația Facebook, Cluj Napoca, Editura Școala Ardeleană, 2015.

5. Dowell, Josh Mc., Generația înstrăinată. Un pod peste prăpastia dintre generații, Oradea, Scriptum, 2005.

6. LEDURE, Yves, Secularisation et spiritualite. Approche anthropologique du christianisme, Bruxelles, Lessius, 2015.

7. MANENT, Pierre, Musulmanii, obstacolul inedit, Iași, Adenium, 2016.

8. MAYER, Jean-Francois Sectele. Neconformisme creștine și noi religii, București, Enciclopedică, 1998.

9. PEETERS, Margherite A., Il Gender. Una questione politica e culturale, San Paolo, 2014.

10. Postman, Neil, Distracția care ne omoară. Discursul public în epoca televizorului, București, Anacronic, 2016.

11. RICCI, Giancarlo, Sessualita e politica.Viaggio nell'arcipelago gender, Sugarco Edizioni, 2016.

12. Rosmini, Antonio, Cele cinci plăgi ale Sfintei Biserici. Principii pentru desăvârșirea creștinească (Tratat dedicat clerului catolic), Iași, Institutul European, 2007.

13. SILBERMAN, Steve, Neurotriburi. Istoria uitată a autismului, București, Frontiera, 2016.

14. STAN, Emil, Spațiul public și educația la vechii greci, Iași, Institutul European, 2003.

15. Villacanas, Jose Luis, Populismo, Huerta Grande Editorial, 2015. 


\section{Web sources:}

16. http://basilica.ro/documentele-oficiale-ale-sfantului-si-marelui-sinodin-limba-romana/.

17. https://www.holycouncil.org/. 